\title{
PENGARUH INTERVAL PEMBERIAN ZAT PERANGSANG TUMBUH INDOLE BUTYRIC ACID (IBA) TERHADAP PERKECAMBAHAN LONTAR (Borassus Sundaicus Becc)
}

\author{
Jitron Eliaser Tameon ${ }^{1}$, IN Widiartha Mahayasa \\ Fakultas Pertanian Universitas Nusa Cendana
}

\begin{abstract}
This research has done in experiment garden of UNDANA ,Faculty of agriculture from september 2010 to desembar 2010. The objective of this research is to find out the interval effect of giving indole butyric acid to the germination of papyrus (Borassus sundaicus Becc)

This research used randomized complete exprimental (RAL)with five treatments and four re-treatments, parameter that has been observev involued longer of root,diamater of root,time of growth of root,total of root,langer of root,time of growth of koleoptil and the dry weight of root.

The result of this reseach conclude that the interval effectof giving the growth regulator of indole butyric acid (IBA) to the germination of papyrus in the everage of dry weight of root.where as the others observation variables are the longer everage of apokol in the $2^{\text {th }}$ week observation, $3^{\text {th }}$ week observation, $4^{\text {th }}$ week observation, $5^{\text {th }}$ week observation, $6^{\text {th }}$ week observation and $8^{\text {th }}$ week observation have significanthy effect.effect of treatments as a result of interval different is not unreal in the observation variables of longer of apokol in the $2^{\text {th }}$ week observation and $7^{\text {th }}$ week observation,time of growth of root,total of root and time of growth of koleoptil.
\end{abstract}

\section{Latar Belakang}

Tanaman lontar (Borassus

sundaicus Becc) merupakan tanaman

serbaguna bagi masyarakat Nusa

Tenggara Timur. Bagi sebagian

penduduk mengolah tanaman lontar

merupakan mata pencaharian utama

sejak dahulu, namun demikian,

kurangnya informasi menyebabkan

tanaman tersebut belum dibudidayakan.
Secara agronomi, budidaya lontar tidaklah terlalu sulit. Perbanyakan tanaman lontar umumnya menggunakan biji dengan cara langsung meletakkannya ke tanah tanpa menyemainya terlebih dahulu. Bibit lontar amat sensitif karena memindahkan pada saat disemai (tanaman muda) sangatlah sulit dan rawan mati. 
Jitron: Pengaruh interval pemberian zat perangsang tumbuh Indole Butyric Acid (IBA) terhadap perkecambahan lontar (Borassus Sundaicus Becc)

Mahayasa (2006) mengatakan perkembangan buah, mencegah

bahwa biji tanaman lontar memiliki kerontokan, pendorong kegiatan

pola yang tidak sama dengan pada kambium dan lain-lain (Anonim, 2010).

umumnya tanaman lainya, bahkan tidak Kusumo (1984) mengemukakan bahwa

juga dengan kebanyakan tanaman dari IBA mempunyai sifat yang lebih baik

jenis yang sama yaitu dari jenis palmae. dan efektif dari pada IAA dan NAA.

Biji tanaman lontar akan sulit untuk Karena kandungan kimianya lebih stabil

tumbuh jika dipindahkan ke tempat lain

yang diinginkan walaupun berdaun satu.

Hal demikian sangat berhubungan

dengan pola perkecambahan benih

lontar.

Perkecambahan lontar dapat

dilakukan dengan menggunakan zat

perangsang tumbuh. Salah satu zat

perangsang yang dapat dimanfaatkan

adalah Indole Butyric Acid (IBA).

Indole Butyric Acid (IBA) adalah salah

satu perangsang tumbuh yang termasuk

dalam kelompok auksin. Selain dipakai

untuk merangsang pertumbuhan akar,

zat perangsang tumbuh IBA juga

rendah, maka perlu dilakukan penelitian

mempunyai manfaat lain seperti

mengenai Pengaruh Interval Waktu

menambah daya kecambah, merangsang

Pemberian Zat Perangsang Tumbuh 
Jitron: Pengaruh interval pemberian zat perangsang tumbuh Indole Butyric Acid (IBA) terhadap perkecambahan lontar (Borassus Sundaicus Becc)

Indole Butyric Acid (IBA) Terhadap

Perkecambahan Lontar (Borassus

sundaicus Becc).

\section{METODE PENELITIAN}

\section{Tempat Dan Waktu Penelitian}

Penelitian ini telah dilaksanakan di kebun percobaan Fakultas Pertanian Undana Kupang yang berlangsung dari September sampai Desember 2010.

\section{Bahan Dan Peralatan Penelitian}

Bahan dalam penelitian ini adalah benih lontar, ZPT IBA (Indole butyric acid), tanah, pupuk kandang, alkohol 90\% , label, polibag. Alat yang digunakan : Pisau, meter plastik,jangka sorong, ember plastik, sendok, timbangan analitik, oven dan alat tulis menulis.

\section{Rancangan Percobaan}

Rancangan yang digunakan dalam penelitan ini adalah Rancangan Acak Lengkap (RAL) dengan 5 Perlakuan dengan lama interval waktu perendaman yang berbeda dan tingkat konsentrasi
IBA yang sama yaitu I gram IBA/1000ml aguades dengan interval waktu yang berbeda dimana masingmasing perlakuan diulang sebanyak 4 kali sehingga diperoleh 20 satuan percobaan, yaitu: P0 :Tanpa perendaman (kontrol), P1: Perendaman dengan zat perangsang selama 0,5 jam, P2: Perendaman dengan zat perangsang selama 1 jam, P3 : Perendaman dengan zat perangsang selama 1,5 jam dan P4:: Perendaman dengan zat perangsang selama 2 jam.

\section{Analisis Data}

Data yang diperoleh akan dianalisis dengan sidik ragam untuk mengetahui pengaruh perlakuan dan jika ada perlakuan yang berbeda maka akan dilanjutkan dengan menggunakan uji Beda Nyata Terkecil (BNT).

\section{Pelaksanaan Penelitian meliputi:}

Pelaksanaan penelitian meliputi: penyiapan media tanam, persiapan benih, penanaman benih lontar, 
Jitron: Pengaruh interval pemberian zat perangsang tumbuh Indole Butyric Acid (IBA) terhadap perkecambahan lontar (Borassus Sundaicus Becc)

pembuatan zat perangangsang tumbuh

iba, pemberian zat perangsang tumbuh iba.

\section{Parameter Yang Diukur}

Pemberian zat pengatur tumbuh pada tanaman lontar dapat diukur dengan parameter untuk melihat pengaruh yang ditimbulkan pada pertumbuhan kecambah lontar. Parameter ini dapat mengukur secara kuantitas dari pertumbuhan tanaman lontar akibat interval waktu pemberian zat pengatur tumbuh, parameter yang diukur pada penelitian ini meliputi : Panjang Apokol, Diameter Apokol, Waktu Tumbuh Akar, Panjang Akar, Jumlah Akar , Waktu Tumbuh Koleoptil, dan Bobot Kering Akar.

\section{HASIL DAN PEMBAHASAN}

\section{Panjang Apokol}

Data pengamatan dan hasil analisis varian terhadap panjang apokol dari pengamatan minggu I sampai minggu ke VIII disajikan pada Lampiran 2a sampai 9a. Rerata perlakuan interval waktu lama perendaman IBA menunjukkan bahwa berbeda tidak nyata dan secara nyata dan uji lanjut BNT 0,05 disajikan pada tabel I.

Keadaan yang diperlihatkan pada Tabel I menunjukkan bahwa pengamatan minggu I dan minggu ke VII berpengaruh tidak nyata. Sedangkan pada pengamatan minggu $\mathrm{II}, \mathrm{II}, \mathrm{IV}, \mathrm{V}, \mathrm{VI}$ dan minggu ke VIII berpengaruh secara nyata terhadap panjang apokol. Pada pengamatan minggu $\mathrm{II}, \mathrm{II}, \mathrm{IV}, \mathrm{V}$ dan minggu ke VIII menghasilkan rerata tertinggi dicapai pada perlakuan p0 (kontrol) kecuali pada pengamatan minggu ke VI menghasilkan rerata tertinggi di capai pada perlakuan interval waktu perendaman 0,5 jam (p1) dan berbeda secara nyata dengan perlakuan lainnya. 
Jitron: Pengaruh interval pemberian zat perangsang tumbuh Indole Butyric Acid (IBA) terhadap perkecambahan lontar (Borassus Sundaicus Becc)

Tabel I . Rata-rata panjang apokol (cm) akibat interval waktu perendaman pada pengamatan minggu I-VIII

\begin{tabular}{|c|c|c|c|c|c|c|c|c|}
\hline \multirow{3}{*}{$\begin{array}{l}\text { PERL } \\
\text { AKU } \\
\text { AN }\end{array}$} & \multicolumn{8}{|c|}{ PANJANG APOKOL } \\
\hline & Minggu & Minggu & Minggu & Minggu & Minggu & Minggu & Minggu & Minggu \\
\hline & I & II & III & IV & $\mathrm{V}$ & VI & VII & VIII \\
\hline p0 & 5,75 & $11,58 \mathbf{b}$ & $21,50 \mathbf{b}$ & $26,75 \mathbf{b}$ & $34,25 \mathbf{b}$ & 43,00 c & 49,0 & $55,65 \quad$ b \\
\hline $\mathrm{p} 1$ & 7,00 & $8,88 \mathbf{a b}$ & $14,50 \mathbf{a b}$ & $20,00 \mathbf{a b}$ & $29,75 \mathbf{a b}$ & $35,00 \mathbf{b c}$ & 40,75 & $45,25 \mathbf{a b}$ \\
\hline $\mathrm{p} 2$ & 5,68 & 5,93 a & $7,80 \mathbf{a}$ & $12,75 \mathbf{a}$ & $19,00 \mathbf{a}$ & $21,50 \mathbf{a}$ & 29,25 & $37,55 \mathbf{a}$ \\
\hline p3 & 5,38 & $5,00 \mathbf{a}$ & $6,50 \mathbf{a}$ & $11,25 \mathbf{a}$ & $18,75 \mathbf{a}$ & $23,75 \mathbf{a}$ & 34,75 & $38,73 \mathbf{a}$ \\
\hline $\mathrm{p} 4$ & 5,00 & $5,00 \mathbf{a}$ & $9,25 \mathbf{a}$ & $15,25 \quad \mathbf{a}$ & $21,75 \mathbf{a}$ & $29,00 \mathbf{a b c}$ & 35,75 & $41,95 \mathbf{a}$ \\
\hline
\end{tabular}

Keterangan : Angka-angka yang diikuti oleh huruf yang sama pada kolom yang sama adalah berbeda tidak nyata pada Uji BNT 5\%

Perbedaan rerata perlakuan interval waktu lama perendaman terhadap panjang apokol dapat di duga bahwa pengaruh lama perendaman IBA dan tingkat pemberian dosis yang belum optimal serta dipengaruhi oleh faktor eksternal dan internal. Hal ini di pertegas oleh Sutopo (1988) menyatakan bahwa banyak faktor yang mempengaruhi proses perkecambahan diantaranya faktor disekitar biji maupun faktor internal biji. Menurut (Panjaitan.2000) Tinggi rendahnya hasil dari penggunaan ZPT tergantung pada beberapa faktor salah satunya adalah lamanya stek direndam dalam larutan, semakin lama stek berada dalam larutan semakin meningkat larutan dalam stek.

\section{Diameter Apokol}

Data pengamatan dan hasil analisis varian terhadap diameter apokol minggu I sampai minggu ke VIII disajikan pada lampiran 10a sampai 17a. Rerata perlakuan interval waktu perendaman IBA dari beberapa minggu pengamatan menunjukkan bahwa berbeda tidak nyata disajikan pada tabel 2 . 
Jitron: Pengaruh interval pemberian zat perangsang tumbuh Indole Butyric Acid (IBA) terhadap perkecambahan lontar (Borassus Sundaicus Becc)

Tabel II. Rara-rata diameter apokol (cm) akibat interval waktu perendaman pada pengamatan minggu I-VIII

\begin{tabular}{|c|c|c|c|c|c|c|c|c|}
\hline \multirow{2}{*}{$\begin{array}{l}\text { PERL } \\
\text { AKUA } \\
\mathrm{N}\end{array}$} & \multicolumn{8}{|c|}{ DIAMETER APOKOL } \\
\hline & $\begin{array}{c}\text { MINGGU } \\
1\end{array}$ & $\begin{array}{c}\text { MINGGU } \\
\text { II }\end{array}$ & $\begin{array}{c}\text { MINGGU } \\
\text { III }\end{array}$ & $\begin{array}{c}\text { MINGGU } \\
\text { IV }\end{array}$ & $\begin{array}{c}\text { MINGGU } \\
\mathrm{V}\end{array}$ & $\begin{array}{c}\text { MINGGU } \\
\text { VI }\end{array}$ & $\begin{array}{c}\text { MINGGU } \\
\text { VII }\end{array}$ & $\begin{array}{c}\text { MINGGU } \\
\text { VIII }\end{array}$ \\
\hline $\mathrm{p} 0$ & 1,50 & 2,80 & 3,15 & 4,25 & 4,25 & 5,55 & 6,75 & 7,48 \\
\hline $\mathrm{p} 1$ & 1,75 & 4,25 & 2,90 & 5,00 & 5,55 & 6,53 & 7,75 & 9,03 \\
\hline $\mathrm{p} 2$ & 1,70 & 2,38 & 4,00 & 4,93 & 4,93 & 5,25 & 6,50 & 6,93 \\
\hline p3 & 1,55 & 3,38 & 3,43 & 4,20 & 4,20 & 5,35 & 6,25 & 6,38 \\
\hline $\mathrm{p} 4$ & 1,63 & 2,80 & 4,20 & 4,70 & 4,70 & 5,40 & 6,50 & 7,03 \\
\hline
\end{tabular}

perendaman IBA 2 jam (p4) berbeda

Keadaan yang diperlihatkan pada

Tabel II menunjukkan bahwa rerata interval waktu lama perendaman IBA dari pengamatan minggu I sampai minggu ke VIII berpengaruh tidak nyata untuk semua perlakuan terhadap diameter apokol. Namun demikian, untuk rerata diameter apokol tertinggi dari pengamatan minggu I,II,V,VI,VII, dan minggu ke VIII dicapai pada perlakuan interval waktu lama perendaman IBA 0,5 jam (p1) kecuali pada pengamatan minggu ke III dan minggu ke IV yang memberikan rerata diameter tertinggi dicapai pada perlakuan interval waktu lama tidak nyata dengan perlakuan lainnya.

Perbedaan rerata perlakuan interval waktu lama perendaman IBA terhadap diameter apokol dapat di sebabkan oleh terjadinya perkembangan dari embrio terutama perkembangan dari calon tunas. Hal ini di pertegas oleh Mahayasa (2005) menyatakan bahwa perkembangan diameter apokol akan mengalami penurunan dengan semakin bertambahnya umur kecambah dan semakin berkurangnya besar diameter dengan semakin bertambahnya umur kecambah lebih disebabkan karena jaringan penyusun dari apokol akan semakin tua dan akhirnya menjadi kering. Ada juga faktor lain yang 
Jitron: Pengaruh interval pemberian zat perangsang tumbuh Indole Butyric Acid (IBA) terhadap perkecambahan lontar (Borassus Sundaicus Becc)

mungkin berpengaruh dalam ukuran

diameter apokol yaitu ketersedian

cadangan makanan untuk menunjang

pertumbuhan dan perkembangan apokol

hal ini dipertegas pula oleh pendapat

Jhiman dan Went (1930) yang

mengemukakan bahwa ukuran

pertumbuhan pada tanaman mengikuti

jumlah persediaan karbohidrat.

\section{Waktu Tumbuh Akar}

Data pengamatan dan hasil analisis varian terhadap rerata waktu tumbuh akar disajikan pada Lampiran 18a. Rerata perlakuan interval waktu lama perendaman IBA terhadap percepatan waktu tumbuh akar menunjukkan berbeda tidak nyata disajikan pada tabel 3.

Tabel III. Data pengamatan waktu tumbuh akar kecambah lontar (HST)

\begin{tabular}{|c|c|}
\hline Perlakuan & Rerata \\
\hline $\mathrm{p} 0$ & 53,50 \\
\hline $\mathrm{p} 1$ & 52,25 \\
\hline $\mathrm{p} 2$ & 53,00 \\
\hline $\mathrm{p} 3$ & 53,75 \\
\hline $\mathrm{p} 4$ & 53,00 \\
\hline
\end{tabular}

Tabel III menunjukkan bahwa secara keseluruhan rerata perlakuan interval waktu lama perendaman IBA terhadap percepatan waktu tumbuh akar berbeda tidak nyata dikarenakan pada ujung apokol auksin lebih banyak karena biasanya kandungan auksin lebih banyak pada jaringan meristem didalam ujung tanaman. Dwijoseputro (1994) mengatakan bahwa auksin banyak tersusun dijaringan-jaringan meristem didalam ujung tanaman hal ini di pertegas lagi oleh (Kusumo,1984) mengatakan bahwa perakaran yang timbul dari stek disebabkan oleh dorongan auksin yang berasal dari tunas dan daun. Pada perlakuan dimana pusat pembentukan koleoptil adalah ujung apokol sehingga akar akan cepat berkembang tanpa diberikan hormon 
Jitron: Pengaruh interval pemberian zat perangsang tumbuh Indole Butyric Acid (IBA) terhadap perkecambahan lontar (Borassus Sundaicus Becc)

karena pada dasarnya auksin yang untuk pembentukan akar. berada pada apokol sudah tersedia

\section{Panjang Akar}

Data pengamatan dan hasil analisis varian terhadap rerata panjang akar disajikan pada lampiran 19a. Rerata perlakuan interval waktu lama perendaman IBA terhadap panjang akar menunjukkan berbeda tidak nyata disajikan pada tabel 4.

Tabel IV. Data pengamatan panjang akar kecambah lontar $(\mathrm{cm})$

\begin{tabular}{|c|c|}
\hline Perlakuan & Rerata \\
\hline $\mathrm{p} 0$ & 11,63 \\
\hline $\mathrm{p} 1$ & 11,10 \\
\hline $\mathrm{p} 2$ & 14,43 \\
\hline $\mathrm{p} 3$ & 15,33 \\
\hline $\mathrm{p} 4$ & 15,20 \\
\hline
\end{tabular}

Tabel IV menunjukkan bahwa secara keseluruhan rerata perlakuan interval waktu lama perendaman IBA terhadap panjang akar berbeda tidak nyata dengan perlakuan lainnya. Hal ini disebabkan oleh penggunaan dosis kurang optimal sehingga belum mampu mempengaruhi pemanjangan akar. Kusumo, 1984 mengemukkan bahwa pengaruh ZPT IBA pada kosentrasi yang lebih tinggi akan menghambat pertumbuhan, meracuni, bahkan mematikan tanaman. Hal yang sama juga dikatakan oleh Lakitan (1995) pada tanaman jati putih bahwa aplikasi dosis IBA yang terlalu tinggi dapat menghambat pertunasan, sedangkan bila terlalu rendah tidak efektif untuk merangsang pertumbuhan akar.

\section{Jumlah Akar}

Data pengamatan dan hasil analisis varian terhadap rerata jumlah akar disajikan pada lampiran 20a. Rerata perlakuan interval waktu lama perendaman IBA terhadap jumlah akar menunjukkan berbeda tidak nyata disajikan pada tabel 5. 
Jitron: Pengaruh interval pemberian zat perangsang tumbuh Indole Butyric Acid (IBA) terhadap perkecambahan lontar (Borassus Sundaicus Becc)

Tabel V. Data pengamatan jumlah akar kecambah lontar

\begin{tabular}{|c|c|}
\hline Perlakuan & Rerata \\
\hline p0 & 2,75 \\
\hline p1 & 5,50 \\
\hline p2 & 2,00 \\
\hline p3 & 4,75 \\
\hline
\end{tabular}

Pada tabel ini dapat dilihat bahwa semua perlakuan menunjukan bahwa pemberian ZPT IBA terhadap apokol lontar tidak berbeda nyata. Tidak adanya pengaruh perlakuan lama perendaman ZPT IBA terhadap jumlah akar diduga akibat kondisi lingkungan yang kurang optimal dan penggunaan dosis yang kurang tepat dapat menyebabkan pembentukan akar juga kurang optimal.

Pengaruh lama perendaman ZPT IBA pada konsentrasi yang lebih tinggi akan menghambat pertumbuhan, meracuni, bahkan mematikan tanaman (Kusumo,1984). Hal ini sesuai dengan pendapat Dwidjoseputro (1990), yang mengemukakan bahwa manfaat dari
ZPT IBA sangat tergantung dari dosis yang diberikan, jika dosisnya tepat akan sangat membantu dan didapatkan sistim perakaran yang baik dalam waktu yang relatif singkat. Danu dan Tampubolon (1993) menemukan hal yang sama pada stek Gamelina arborea Linn yang diberikan perlakuan ZPT IBA, dimana pemberian ZPT IBA tidak menunjukan pengaruh yang nyata terhadap jumlah akar yang dihasilkan.

\section{Waktu Tumbuh Koleoptil}

Data pengamatan dan hasil analisis varian terhadap rerata waktu tumbuh koleoptil disajikan pada lampiran 21a. Rerata perlakuan interval waktu lama perendaman IBA terhadap waktu tumbuh koleoptil menunjukkan 
Jitron: Pengaruh interval pemberian zat perangsang tumbuh Indole Butyric Acid (IBA) terhadap perkecambahan lontar (Borassus Sundaicus Becc)

berbeda tidak nyata disajikan pada tabel 6 .

Tabel VI. Data pengamatan waktu tumbuh koleoptil (HST)

\begin{tabular}{|c|c|}
\hline Perlakuan & Rerata \\
\hline p0 & 69,25 \\
\hline p1 & 69,50 \\
\hline p2 & 69,25 \\
\hline p3 & 69,75 \\
\hline p4 & 68,50 \\
\hline
\end{tabular}

Tabel VI menunjukkan bahwa secara keseluruhan rerata perlakuan interval waktu lama perendaman IBA terhadap percepatan waktu tumbuh koleoptil berbeda tidak nyata dengan perlakuan lainnya. Hal ini disebabkan oleh penggunaan dosis kurang optimal sehingga belum mampu mempengaruhi percepatan waktu tumbuh keleoptil. Kusumo (1984) mengemukkan bahwa tanggapan tanaman terhadap pemberian ZPT sangat bervariasi dan tergantung pada fase perkembangan yang telah dicapainya .

\section{Bobot kering akar}

Data pengamatan dan hasil analisis varian terhadap rerata bobot kering akar disajikan pada Lampiran 22a. Rerata perlakuan interval waktu lama perendaman IBA terhadap bobot kering akar menunjukkan berbeda nyata sedangkan uji lanjut BNT 0,05 disajikan pada tabel 7.

Keadaan yang di perlihatkan pada tabel di atas menunjukkan bahwa retata bobot kering akar tertinggi di capai pada perlakuan interval waktu lama perendaman IBA 2,0 jam (p4) dan 1 jam (p2) berbeda secara nyata dengan perlakuan lainnya. Hal ini dapat diduga karena lama perendaman dan lingkungan yang cukup baik (optimal) mampu menghasilkan bobot kering akar yang didukung dengan pertumbahan dan perkembangan akar. 
Jitron: Pengaruh interval pemberian zat perangsang tumbuh Indole Butyric Acid (IBA) terhadap perkecambahan lontar (Borassus Sundaicus Becc)

Tabel VII. Pengaruh perlakuan interval waktu lama perendaman IBA terhadap rerata bobot kering akar (gram).

\begin{tabular}{|c|c|}
\hline Perlakuan & Rerata \& Notasi \\
\hline p0 & 1,16 a \\
\hline p1 & 1,37 a \\
\hline p2 & 2,40 b \\
\hline p3 & 1,70 a \\
\hline p4 & 2,45 b \\
\hline
\end{tabular}

Keterangan : Angka-angka yang diikuti oleh huruf yang sama adalah berbeda tidak nyata pada Uji BNT 5\%.

Hal ini dikemukakan oleh Kusumo, (1984); Dwijoseputro (1990) Wudianto (1993); mengemukkan bahwa manfaat dari hormon tergantung dosis yang diberikan jika dosisnya tepat akan sangat membantu dan didapatkan sistim perakaran yang baik dalam waktu relatif singkat.

\section{Kesimpulan}

Berdasarkan hasil analisis dan pembahasan di atas dapat disimpulkan bahwa: Pengaruh interval waktu pemberian zat perangsang tumbuh IBA terhadap perkecambahan lontar secara nyata berpegaruh pada rerata panjang apokol minggu II,III,IV,V,VI,VIII dan bobot kering akar. Sedangkan variabel pengamatan yang berbeda tidak nyata terdapat pada variabel pengamatan panjang apokol minggu I dan VII, diameter apokol minggu I sampai ke VIII, waktu tumbuh akar, panjang akar, jumlah akar, dan waktu tumbuh koleoptil.

\section{Ucapan Terima Kasih}

Pada kesempatan ini penulis ingin mengucapkan terima kasih kepada semua pihak yang telah membantu dengan caranya masing-masing dalam melengkapi tulisan ini.

\section{DAFTAR PUSTAKA}

Abidin,Z.1982 Dasar-dasar pengetahuan tentang zat pengatur tumbuh.Penerbit Angkasa, Bandung.

Dwidjosuputro.D.1994. Pengantar Fisiologi Tumbuhan.gramedia Pustaka Utama .Jakarta 
Jitron: Pengaruh interval pemberian zat perangsang tumbuh Indole Butyric Acid (IBA) terhadap perkecambahan lontar (Borassus Sundaicus Becc)

Fisher N.m, R. Peter. 1992. Fisiologi Tanaman Budidaya Tropik. Gajah Mada Univesity Press, Yogyakarta.

Hidayat, R. 1993. Pengaruh IBA dan Triakontanol terhadap Pertumbuhan dan Penyerapan Hara pada Bibit Manggis (Garcinia mangostana L.) dan Fukugi (Garcinia subelliptica Merr). Institute Pertanian Bogor.

Irwanto. 2001. Pengaruh Hormon IBA (Indole Butyric Acid) terhadap Persen Jadi Stek Pucuk Meranti Putih (Shorea montigena). Universitas Pattimura. Ambon.

Jogo.2000.pengaruh perbedaan media tanam terhadap pertumbuhan awal tanaman lontar (Borassus sundaicus,Becc).Universitas Nusa Cendana. Kupang.

Lutong, T.L., 1993. Tanaman Sumber Pemanis. Penebar Swadaya. Jakarta.cademic Press. New York and London.

Mahayasa, I N. W. 2006. Karakteristik Pola Perkecambahan Tanaman Lontar(Borassus sundaicus Becc) secara Alami di Lapangan. Laporan penelitian Fakultas Pertanian Universitas Nusa Cendana(tidak dipublikasikan).

Mahayasa, I N. W. 2006. Pengaruh Tinggi Pot terhadap Perkecambahan Tanaman Lontar(Borassus Sundaicus. Becc) Pada Tingkat Kelembaban Tanah Yang Berbeda.
Program Pascasarjana Universitas Brawijaya. Disertasi (tidak dipublikasikan).

Panjaitan .M. 2000. Pengaruh konsentrasi IBA dan lama perendaman terhadap presentasi keberhasilan pertumbuhan stek pucuk jeruk nipis. skripsi. fakultas pertanian.universitas katolik santo Thomas Sumatera Utara Medan

Rismunandar. 1995. Hormon Tanaman dan Ternak. Penebar Swadaya, Jakarta

Saleh, M.S., 2002b. Perlakuan Fisik dan Konsentrasi Kalium Nitrat untuk Mempercepat Perkecambahan Benih Aren. J. Agroland 10 (4): 346 - 351.

Sulastri,2004. Pengaruh Konsentrasi Indole Butiryc Acid (IBA) dan Lama Perendaman Terhadap Pertumbuhan Stek Pucuk Jambu Air (Syzygium Semarangense Burm.S.Alst) skripsi. fakultas pertanian.universitas katolik santo Thomas Sumatera Utara Medan

Sutopo, L., 2002. Teknologi Benih (Edisi Revisi).Fakultas Pertanian UNBRAW. PT Raja GrafindoPersada. Jakarta.

Sustrosupadi adji. 2000. Rancangan percobaan praktis bidang pertanian. edisi .revisi.Kanisius.yogyakarta.

Wudianto.1996.Membuat Stek,Cangkok dan Okulasi.Penebar Swadaya.Jakarta 